\title{
Lack of Association Between TNF $\alpha$-308 Polymorphism and End Stage Renal Disease in North Indian Population
}

\author{
Kapil Mohindru, Harish Changotra and P.K. Sehajpal* \\ Department of Molecular Biology and Biochemistry, Guru Nanak Dev University, \\ Amritsar 143 005, Punjab, India
}

KEYWORDS TNF- $\alpha$; ESRD; polymorphisms; SNP

\begin{abstract}
Cytokines, play a critical role in the pathophysiology of End Stage Renal Disease (ESRD). Tumor necrosis factor, TNF- $\alpha$, is a multifunctional cytokine implicated in modulating the progression of ESRD. The promoter of TNF- $\alpha$ gene has many biallelic variations but the one at -308 (G-308 A) relative to transcription start site has extensively been studied and reported to have implications in acute and chronic rejection after renal transplant, the best renal replacement therapy available to ESRD patients. The present study was undertaken to evaluate the role of a single nucleotide polymorphism at -308 site in the promoter of TNF- $\alpha$ gene in ESRD in North Indian population. Samples from 111 diabetic nephropathy patients with ESRD and 164 random controls were genotyped using amplification refractory mutation system analysis for this polymorphism. The two groups revealed no significant differences with respect to the distribution of-308 polymorphic genotypes or allele frequencies. The data strongly suggest a lack of association between TNF- $\alpha-308$ polymorphism and ESRD in the North Indian population and lend support to the argument that the association of A allele (high TNF- $\alpha$ producer) with transplant rejection may reside with the involvement of this allele in the process of rejection.
\end{abstract}

\section{INTRODUCTION}

ESRD is a term used for kidney failure patients who are permanently dependent upon renal replacement therapy (dialysis or transplantation) in order to avoid life-threatening uremia (Levey et al. 2003). In India, it is difficult to decipher the exact number of patients afflicted with this disease due to the lack of national registries; however, using most conservative estimates it is estimated that around 100,000 fresh patients are added each year to the existing pool of patients (Sakuja et al. 1994). Diabetic nephropathy and hypertension are two leading causes for the development of ESRD (Young 1997). Diabetic nephropathy is a common complication of diabetic mellitus and is shown to be influenced by genetic factors (Chaudhary et al. 1999). Several investigators have implicated tumor necrosis factor-alpha (TNF- $\alpha$ ) cytokine in modulating the progression of ESRD (Sankaran et al. 1999; Klahr 1999). The promoter of TNF- $\alpha$ gene has many single nucleotide polymorphisms (SNP) but the one at

*Address correspondence to: Dr P.K. Sehajpal, Department of Molecular Biology and Biochemistry, Guru Nanak Dev University, Amritsar 143 005, Punjab, India

Telephone: +91-183-2258802-09 Ext $3312(\mathrm{O})$

+91-183-2256 290 (R)

E mail:sehajpalpk@yahoo.com
-308 (G-308 A) relative to transcription start site has extensively been studied (Wilson et al. 1992; Wilson et al. 1997; Hutchinson et al. 1998). The in vitro and in vivo data strongly alludes to the association of A allele with its high production. Keeping in view, the extent of the ESRD disease and the huge cost incurred for renal transplantation, the best renal replacement therapy (RRT) available to ESRD patients, new strategies are urgently needed for the better management of this chronic disease. The present study was, thus, undertaken to evaluate the role of a SNP at -308 site in TNF- $\alpha$ promoter as a risk factor in the development of ESRD.

\section{MATERIAL AND METHOD}

Peripheral blood samples were collected from 111 diabetic nephropathy patients with ESRD and 164 , age and sex matched, normal controls inhabiting the North Indian state of Punjab and adjoining areas. DNA was isolated from blood samples using inorganic method (Miller et al. 1988). The TNF- $\alpha-308$ polymorphisms was studied employing ARMS-PCR as described by Gupta and Sehajpal (2003). Briefly, the optimized reaction conditions consisted of $40 \mathrm{ng}$ of genomic DNA in a total volume of $30 \mu \mathrm{l}$ of reaction mixture containing $0.16 \mu \mathrm{M}$ of each 
primer, $30 \mu \mathrm{M}$ of each dNTP, $10 \mathrm{mM}$ Tris- $\mathrm{HCl}(\mathrm{pH}$ 9.0), $1.5 \mathrm{mM} \mathrm{MgCl}_{2}, 50 \mathrm{mM} \mathrm{KCl}, 0.01 \%$ gelatin and 0.3 unit of Taq DNA polymerase (Bangalore Genei, Bangalore). The reaction was amplified for 35 cycles, each cycle consisted of denaturation at $94^{\circ} \mathrm{C}$ for $30 \mathrm{sec}$, annealing at $57^{\circ} \mathrm{C}$ for $20 \mathrm{sec}$, extension at $72^{\circ} \mathrm{C}$ for $20 \mathrm{sec}$ and finally a 3 min extension at $72^{\circ} \mathrm{C}$.

\section{RESULTS AND DISCUSSION}

Figure 1 represents a typical agarose gel of amplified products. Upper and lower panels of the gel show the PCR products amplified with primers AP1 (specific for $G$ allele) \& CP and AP2 (specific for $A$ allele) \& CP, respectively. Lanes 26 shows the randomly screened samples for determination of genotypes, represented at the bottom of the gel. Lanes 1 and 7 represent known control samples of GG and AA genotypes, respectively. It is evident from table 1 that the incidence of homozygote for $G$ allele (GG) for this polymorphism were higher in the control group $(84.15 \%)$ than the ESRD patients ( $82.88 \%$ ), while the incidence of heterozygote (GA) $(13.52 \%)$ and homozygote (AA) for $A$ allele $(3.60 \%)$ are marginally higher in ESRD group then the controls $(13.41 \%)$ and $(2.44 \%)$, respectively.
No significant differences in the distribution of genotypes $\left(\chi^{2}=0.321, \mathrm{p}=0.1483, \mathrm{df}=2\right)$ and polymorphic alleles was observed in diabetic nephropathy ESRD patients and control population.

Table 2 exhibits a wide variation $(0.068-0.274)$ in the incidence of $A$ allele in different populations of the world (Gupta and Sehajpal 2003; Kam et al. 1999; Witte et al. 2002; Westendorp et al. 1997; Schaaf et al. 2001; Lio et al. 2003; Perrey et al. 1998; Meenagh et al. 2002). It is interesting to note that the frequency of the $A$ allele was found to be lowest (0.068) amongst the North Indian population of Punjab, followed by 0.091 in the present investigation. The highest frequency $(0.274)$ was recorded in a Caucasian population from Manchester (UK).

ESRD is a human clinical disorder where renal transplantation is the best possible therapy. Keeping in view the Indian population structure and its gross GDP value, it won't be unfair to presume that a large number of patients afflicted with this disease die as they cannot afford either renal transplantation or renal dialysis for long duration of time due to the lack of adequate funds to support these clinical procedures. Under such circumstances, it would be prudent to identify

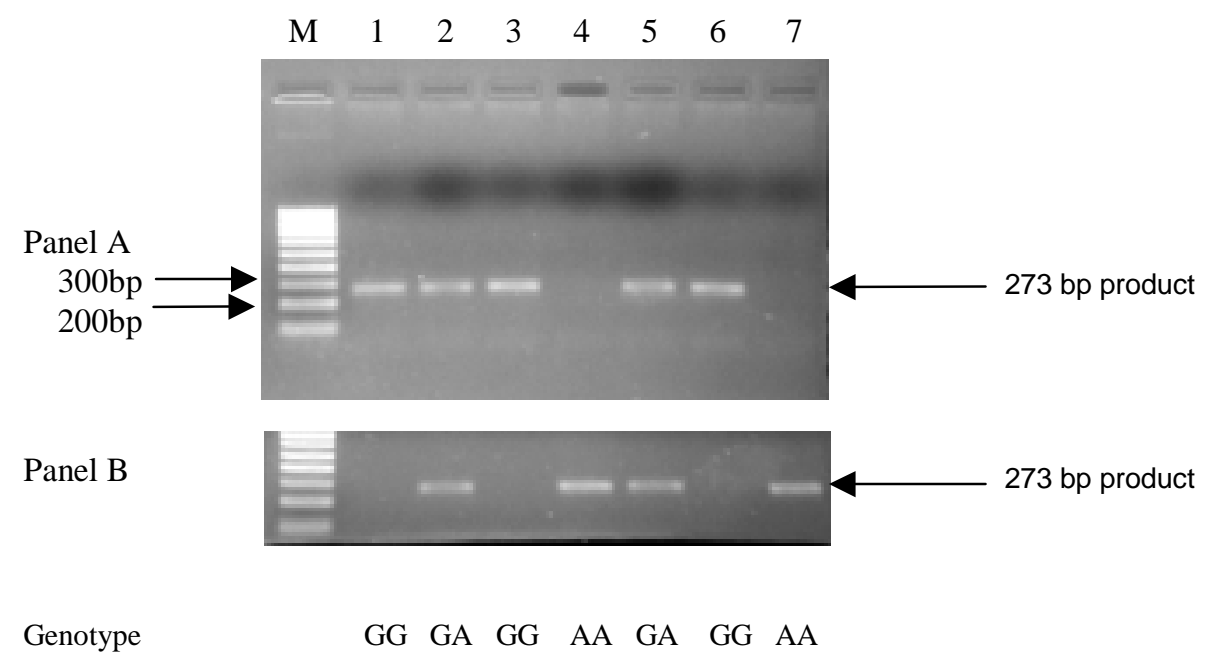

Fig. 1. A representative agarose gel photograph of the G-308A TNF- $\alpha$ polymorphism. The panels $A$ and B depict the DNA samples amplified with AP-1(:5' ATAGGTTTTGAGGGGCATCG 3') \& CP (CP: 5, AAGAATCATTCAACCAGCGG 3') and AP-2 (5' ATAGGTTTTGAGGGGCATCA 3') \& CP, primer pairs, respectively. Lanes $M$ represents 100 bp ladder. Lane 1 and 7 represents known samples of GG and AA genotypes, respectively. Lane 2-6 corresponds to random samples screened for $\mathbf{- 3 0 8}$ polymorphism. The genotypes of the samples are noted at the bottom of the figure. 
TNF $\alpha-308$ POLYMORPHISMS AND ESRD

Table 1: Genotypic distribution of TNF- $\alpha-308$ polymorphism in control and ESRD populations

\begin{tabular}{|c|c|c|c|c|c|}
\hline \multirow[t]{2}{*}{ Population studied } & \multicolumn{3}{|c|}{ Genotypes (Percentage) } & \multicolumn{2}{|c|}{ Allele frequency } \\
\hline & $G G$ & $G A$ & $A A$ & $G$ & $A$ \\
\hline ESRD $\quad(n=111)$ & $92(82.88)$ & $15(13.52)$ & $4(3.60)$ & 0.896 & 0.104 \\
\hline Control $(n=164)$ & $138(84.15)$ & $22(13.41)$ & $4(2.44)$ & 0.909 & 0.091 \\
\hline
\end{tabular}

Chi square ( ESRD vs control) d.f. $2=0.321$

Table 2: Genotypic and allelic distribution of TNF- $\alpha-308$ polymorphism in different populations

\begin{tabular}{|c|c|c|c|c|c|c|}
\hline \multirow[t]{2}{*}{ Population studied } & \multicolumn{3}{|c|}{ Genotypes number (Percentage) } & \multicolumn{2}{|c|}{ Allele frequency } & \multirow[t]{2}{*}{ Reference } \\
\hline & $G G$ & $G A$ & $A A$ & $G$ & $A$ & \\
\hline North India, India & $138(84.2)$ & $22(13.4)$ & $4(2.4)$ & 0.909 & 0.091 & Present study \\
\hline Punjab, India & $165(86.8)$ & $24(12.6)$ & $1(0.5)$ & 0.932 & 0.068 & Gupta and Sehajpal (2003) \\
\hline Nottingham, England & $96(62.7)$ & $52(33.9)$ & $5(3.2)$ & 0.797 & 0.202 & Kam et al. (1999) \\
\hline California, USA & $212(78.0)$ & $55(20.0)$ & $6(2.0)$ & 0.877 & 0.122 & Witte et al. (2002) \\
\hline Leiden, Netherlands & $50(57.0)$ & $34(34.0)$ & $4(2.0)$ & 0.761 & 0.238 & Westendorp et al. (1997) \\
\hline Kiel, Germany & $143(66.2)$ & $63(29.6)$ & $10(4.6)$ & 0.81 & 0.19 & Schaaf et al. (2001) \\
\hline Central and Southern Italy & $83(72.2)$ & $31(26.9)$ & $1(0.8)$ & 0.857 & 0.143 & Lio et al. (2003) \\
\hline Manchester, UK & $65(61.3)$ & $24(22.6)$ & $17(16.0)$ & 0.726 & 0.274 & Perry et al. (1998) \\
\hline N. Ireland, UK & $61(61.0)$ & $32(32.0)$ & $7(7.0)$ & 0.77 & 0.23 & Meenagh et al. (2002) \\
\hline Natal, (Zulu), South Africa & $54(62.8)$ & $26(30.2)$ & $6(7.0)$ & 0.779 & 0.221 & Meenagh et al. (2002) \\
\hline Singapore, Chinese & $64(77.1)$ & $18(21.7)$ & $1(1.2)$ & 0.88 & 0.12 & Meenagh et al. (2002) \\
\hline
\end{tabular}

strategies that could help in the early identification of patients with high risk of developing ESRD or to look for ways that could delay the onset of this disease or modulate its course of infection.

Cytokines play a critical role in the pathophysiology of ESRD. Johnston et al. (1998) observed increased turn over of various cytokines in ESRD and suggested that genetic factors play a significant role in susceptibility of this disease in patients of African descent. Hutchinson et al. (1998) demonstrated that individuals differ in their capacity to synthesize various cytokines and attributed such differences to the existence of allelic polymorphism in the promoter region of cytokines. Tumor necrosis factor- $\alpha$ is a multifunctional cytokine implicated in modulating the progression of chronic renal failure to ESRD (Sankaran et al. 1999; Klahr 1999). Studies form different parts of the world suggest the association of A allele, high TNF- $\alpha$ producer, with acute rejection of renal transplant (Hassan et al. 2003; Ram et al. 2003). Although, this observation is not shared by all, Marshall et al. (2000) failed to find such association with renal graft rejection in their population. The present study was undertaken to investigate the association of TNF- $\alpha-308$ allelic polymorphism and ESRD as no such data is available for Indian populations. The data obtained using 111 diabetic nephropathy ESRD patients and 164 controls clearly suggest a lack of association between TNF- $\alpha-308$ polymorphism and ESRD in our population (chi-square value $=0.321, \mathrm{df}=2$ ). These findings are in accordance with an earlier report (Poli et al. 2000) and lend support to the argument that the association of $\mathrm{A}$ allele with transplant rejection may reside with the involvement of this allele in the process of rejection. Given the wide variation observed in the incidence of this allele, it seems plausible that ethnic background of the population could as well play a role in this process. In conclusion, the result of this study indicates that TNF- $\alpha-308$ promoter polymorphisms in not associated with ESRD in our population.

\section{ACKNOWLEDGEMENTS}

HC is thankful to CSIR, New Delhi, India for the award of a Senior Research Fellowship.

\section{REFERENCES}

Chowdhury TA, Dyer PH, Kumar H, Barnett AH, Bain SC 1999. Genetic determinants of diabetic nephropathy. Clin Sci (Colch), 96: 221-230.

Gupta V, Sehajpal PK 2003. Rapid detection of single nucleotide (-308) polymorphism in TNF-á promoter using ARMS-PCR. Curr Sci, 85: 1521-1523.

Hassan MI, Aschner Y, Manning CH, Xu J, Aschner JL 2003. Racial differences in selected cytokine allelic and genotypic frequencies among healthy, pregnant women in North Carolina. Cytokine, 21: 10-16.

Hutchinson IV, Pravica V, Sinott PJ 1998. Genetic 
regulation of cytokine synthesis: Consequences for acute and chronic allograft rejection. Graft, 1: 186192.

Johnston CI, Risvanis J, Naitoh M, Tikkanen I 1998. Mechanism of progression of renal disease: current hemodynamic concepts. J Hypertens, 16(suppl): S3-7.

Kam L, Wa TC, Mansur AH, Britton J, Williams G, Pavord I, Richards K, Campbell DA, Morton N, Holgate ST, Morrison JF 1999. Association between -308 tumor necrosis factor promoter polymorphism and bronchial hyperreactivity in asthma. Clin Exp Allergy, 29: 1204-1208.

Klahr S. 1999. Mechanisms of progression of chronic renal damage. J Nephrol, 12(suppl): S53-62.

Levey AS, Coresh J, Balk E, Kausz AT, Levin A, Steffes MW, Hogg RJ, Perrone RD, Lau J, Eknoyan G 2003. National Kidney Foundation Practice Guidelines for Chronic Kidney Disease: Evaluation, Classification, and Stratification. Ann Intern Med, 139: 137-147.

Lio D, Scola L, Crivello A, Colonna-Romano G, Candore G, Bonafè M, Cavallone, Marchegiani F, Olivieri F, Franceschi C, Caruso C 2003. Inflammation, genetics, and Longevity: further studies on the protective effects in men of IL-1082 promoter SNP and its interaction with TNF- $\alpha-308$ promoter SNP. J Med Genet, 40: 296-299.

Marshall SE, McLaren AJ, Haldar NA, Bunce M, Morris PJ, Welsh KI 2000. The impact of recipient cytokine genotype on acute rejection after renal transplantation. Transplantation, 70: 1485-1491.

Meenagh A, Williams F, Ross OA, Patterson C, Gorodezky C, Hammond M, Leheny WA, Middleton D 2002. Frequency of cytokine polymorphisms in populations from Western Europe, Africa, Asia, the Middle East and South America. Hum Immunol, 63: $1055-1061$.

Miller SA, Dykes DD, Polesky HF 1988. A simple salting out procedure for extracting of DNA from human nucleated cells. Nucleic Acids Res, 16: 1215.

Perrey C, Pravica V, Sinnott PJ, Hutchinson IV 1998. Genotyping for polymorphisms in interferon- $\gamma$, interleukin-10, transforming growth factor- $\beta 1$ and tumor necrosis factor- $\alpha$ genes: A technical report.
Trans Immunol, 6: 193-197.

Poli F, Boschiero L, Giannoni F, Tonini M, Scalamogna M, Ancona G, Sirchia G 2000. Tumor necrosis factor-alpha gene polymorphism: Implications in kidney transplantation. Cytokine, 12: 1778-1783.

Ram S, Bass K, Abreo K, Baier RJ, Kruger TE 2003. Tumor necrosis factor-alpha-308 polymorphism is associated with synthetic hemodialysis graft failure. J Investig Med, 51: 19-26.

Sakhuja V, Jha V, Ghosh AK, Ahmed S, Saha TK 1994. Chronic renal failure in India. Nephrol Dial Transplant, 9: 871-872.

Sankaran D, Asderakis A, Ashraf S, Roberts IS, Short CD, Dyer PA, Sinnott PJ, Hutchinson IV 1999. Cytokine gene polymorphisms predict acute graft rejection following renal transplantation. Kidney Int, 56: 281-288.

Schaaf BM, Seitzer U, Pravica V, Aries SP, Zabel P 2001. Tumor necrosis factor-alpha -308 promoter gene polymorphism and increased tumor necrosis factor serum bioactivity in farmer's lung patients. $A m J$ Respir Crit Care Med, 163: 379-382.

Westendorp RG, Langermans JA, Huizinga TW, Elouali $\mathrm{AH}$, Verweij CL, Boomsma DI, Vandenbroucke JP, Vandenbrouke JP 1997. Genetic influence on cytokine production and fatal meningococcal disease. Lancet, 349: 170-173.

Wilson AG, di Giovine FS, Blakemore AI, Duff GW 1992. Single base polymorphism in the human tumour necrosis factor alpha (TNF alpha) gene detectable by NcoI restriction of PCR product. Hum Mol Genet, 1: 353

Wilson AG, Symons JA, McDowell TL, McDevitt HO, Duff GW 1997. Effects of a polymorphism in the human tumor necrosis factor-á promoter on transcriptional activation. Proc Natl Acad Sci USA, 94: 3195-3199.

Witte JS, Palmer LJ, O'Connor RD, Hopkins PJ, Hall JM 2002. Relation between tumour necrosis factor polymorphism TNFalpha-308 and risk of asthma. Eur J Hum Genet, 10: 82-85.

Young EW 1997. An improved understanding of the causes of End Stage Renal Disease. Semin Nephrol, 17: $170-175$ 